\title{
PENGARUH KOMPETENSI SUMBER DAYA INSANI TERHADAP MUTU PELAYANAN DAN KINERJA SELAMA ERA NEW NORMAL PADA BMT AL-ITTIHAD MENURUT KONSEP EKONOMI SYARIAH
}

\author{
Syarifah Aini \\ Mahyarni \\ Heri Sunandar \\ Universitas Islam Negeri Sultan Syarif Kasim Riau \\ E-mail:Syarifahainitambunan96@gmail.com
}

\begin{abstract}
Abstrak
Virus Covid-19 di Indonesia memberikan perubahan kegiatan pelayanan yang diberikan pihak BMT Al-Ittihad. Pegawai pada kesehariannya terbiasa berinteraksi secara langsung kepada nasabah, karena adanya COVID-19 maka pegawai mulai terbiasa dengan era new normal dengan menerapkan protokol kesahatan. Penelitian bertujuan untuk mengetahui pengaruh kompetensi sumber daya insani terhadap mutu pelayanan dan kinerja selama era new normal pada BMT Al-Ittihad. Penelitian dilakukan di BMT Al-Ittihad dan merupakan penelitian kuantitatif dengan menggunakan software SPSS. Dari penelitian yang telah dilakukan, maka diperoleh hasil variabel pengalaman kerja, pendidikan, pengetahuan dan keterampilan berpengaruh positif dan signifikan terhadap mutu pelayanan pada BMT Al-Ittihad selama era new normal. Variabel pengalaman kerja, pendidikan, pengetahuan, keterampilan dan mutu pelayanan berpengaruh positif dan signifikan terhadap kinerja pada BMT Al-Ittihad selama era new normal. Selanjutnya tinjauan ekonomi Syariah, kompetensi sumber daya insani terhadap mutu pelayanan dan kinerja selama era new normal pada BMT Al-Ittihad telah sesuai dengan perspektif ekonomi Syariah.
\end{abstract}

Kata Kunci: Kompetensi, Mutu Pelayanan dan Kinerja

\begin{abstract}
The Covid-19 virus in Indonesia has changed the service activities provided by BMT Al-Ittihad. Employees are used to interact everyday directly to customers, because of COVID-19, employees get used to the new normal era by implementing health protocols. This study aims to determine the effect of human resource competence on service quality and performance during the new normal era at BMT Al-Ittihad. The research was conducted at BMT AlIttihad and quantitative resource using software SPSS. From the research that
\end{abstract}


has been done, the results obtained that the variables of work experience, education, knowledge and skills have a positive and significant effect on the quality of service at BMT Al-Ittihad during the new normal era. The variables of work experience, education, knowledge, skills and service quality have a positive and significant effect on performance at BMT Al-Ittihad during the new normal era. Furthermore, a review of the Islamic economy, the competence of human resources on service quality and performance during the new normal era at BMT Al-Ittihad has been in accordance with the perspective of Islamic economics.

Keywords: Competence, Service Quality and Performance

\section{Pendahuluan}

Indonesia adalah salah satu negara berkembang yang memerlukan Sumber Daya Insani (SDI) yang berkualitas agar dapat memberikan suatu prestasi yang cukup terhadap perkembangan kemajuan pembangunan negara. SDI memiliki beberapa pengaruh penting diantaranya dapat mempengaruhi keberhasilan dan kemampuan dalam organisasi. Mengoperasikan tugas dan fungsi organisasi merupakan kewajiban dari SDI. Melakukan kegiatan yang dapat meningkatkan pengetahuan dan keterampilan merupakan peran penting SDI agar terwujudnya organisasi yang memiliki kemajuan. SDI yang memiliki keahlian dan kecakapan dalam melaksanakan tugas akan memberikan kontribusi besar terhadap pencapaian tujuan dalam organisasi. ${ }^{1}$

Menurut Henry Hartanti, SDI adalah sebagai salah satu faktor penentu keberhasilan atau kegagalan organisasi dalam mencapai tujuan, baik itu pada organisasi publik atau private. Dalam perspektif manajemen strategi, SDI merupakan human capital dan intellectual sebagai penentu efektivitas dari faktor-faktor yang lain, seperti: modal, peralatan dan struktur. Keahlian (skill), pengalaman (experience) dan pengetahuan (knowledge) merupakan fungsi dari Human capital. ${ }^{2}$

Menurut Ahmad Mujahidin, baitul mal merupakan tempat penghimpun dana yang harus dimiliki pemerintah, sebagai institusi yang menjamin kehidupan sosial masyarakat (Mujahidin, 2007). Upaya BMT membantu pengembangan usaha mikro terutama dalam hal permodalan. Permodalan membantu melancarkan usaha tersebut, istilah pembiayaan (financing) yang biasa dikenal merupakan khazanah keuangan modern, maka BMT berupaya

${ }^{1}$ Shonia Lingga Pratiwi dan Hendry Cahyono, Pengaruh Pendidikan Dan Pelatihan Terhadap Peningkatan Kualitas SDM Bank Syariah Pada Bank Syariah Mandiri KCP Lamongan, Jurnal Ekonomi Islam, Volume 1 Nomor 2, Tahun 2018, hlm. 146. Diakses pada tanggal 8 Agustus 2020.

2 Henry Hartanti, Pengaruh Kompetensi, Disiplin Kerja, Pendidikan dan Pelatihan Terhadap Kinerja Pegawai pada Dinas Perdagangan Bantul, (Tesis, STIE Widya Wiwaha Yogyakarta, 2018), hlm. 1-2. 
untuk menghimpun dana, terutama dana yang bersumber dari masyarakat lokal atau sekitarnya. BMT memiliki prinsip dalam organisasinya untuk saling tolong menolong antara masyarakat suatu wilayah atau komunitas dalam masalah ekonomi. ${ }^{3}$ Baitul Mal wat Tamwil Al-Ittihad mulai beroperasi 15 Juni 2000, BMT Al-Ittihad merupakan salah satu BMT yang ada di Indonesia, berikut kantor BMT Al-Ittihad di Indonesia dapat dilihat seperti yang di tampilkan pada tabel 1.1 di bawah ini:

Tabel.1

Kantor BMT Al-Ittihad

\begin{tabular}{|c|l|l|}
\hline No & \multicolumn{1}{|c|}{ KANTOR } & \multicolumn{1}{c|}{ ALAMAT } \\
\hline 1 & Kantor Pusat & $\begin{array}{l}\text { Jalan. Damar No.610, Camp PT.CPI,Rumbai, } \\
\text { Pekanbaru }\end{array}$ \\
\hline 2 & Kantor Cabang Rumbai & Jalan.Sembilang NO.107, Rumbai Pesisir \\
\hline 3 & Kantor Cabang Duri & $\begin{array}{l}\text { Jalan.Mawar No.9, Mandau, Duri, } \\
\text { Kab.Bengkalis }\end{array}$ \\
\hline 4 & Kantor Cabang Panam & $\begin{array}{l}\text { Jalan.Delima No.138, Kelurahan.Delima } \\
\text { Kecamatan.Tampan Panam, Pekanbaru }\end{array}$ \\
\hline 5 & Kantor Cabang Cibubur & $\begin{array}{l}\text { Jalan.Ruko Concordia \& Trafalgar Blok H22 } \\
\text { Kota Wisata Ciangsana Gunung utri, Bogor, } \\
\text { Jawa Barat }\end{array}$ \\
\hline
\end{tabular}

Sumber: Profil KSPPS BMT AL-ITTIHAD 2019.

Dapat di lihat pada Tabel.1 di atas kantor pusat dan beberapa kantor cabang BMT Al-Ittihad. BMT Al-Ittihad merupakan salah satu BMT yang selalu berusaha untuk meningkatkan mutu dan kualitas pelayanan yang akan diberikan kepada nasabahnya, guna untuk memberikan kepuasan kepada nasabah sehingga berakibat menghasilkan nilai tambah bagi perusahaan. Salah satu nilai-nilai yang terdapat pada BMT Al-Ittihad adalah berkembang sesuai syari'ah, berakhlak mulia sesuai ajaran Al-Qur'an dan Sunnah, menghargai nasabah sebagai bagian integral kemajuan BMT, mengutamakan ukhwah Islamiyah dan saling menolong dalam kebajikan.

Kompetensi menjelaskan apa yang dilakukan orang di tempat kerja pada berbagai tingkatan dan memperinci standar masing-masing tingkatan, mengidentifikasi karakteristik, pengetahuan dan keterampilan yang diperlukan oleh individu yang memungkinkan menjalankan tugas dan tanggung jawab secara efektif sehingga mencapai standar kualitas profesional dalam bekerja, dan mencakup semua aspek catatan manajemen kinerja,

${ }^{3}$ Euis Amalia, Keadilan Distributif Dalam Ekonomi Islam, (Jakarta: PT.Rajagrafindo Persada, 2009), hlm. 83. 
keterampilan dan pengetahuan tertentu, sikap, komunikasi, aplikasi dan pengembangan. Dengan demikian, kompetensi menjadi sangat berguna untuk membantu organisasi menciptakan budaya kinerja tinggi. Kompetensi sangat diperlukan dalam setiap proses sumber daya manusia, seleksi karyawan, manajemen kerja, perencanaan, dan sebagainya. ${ }^{4}$

Seorang pegawai memiliki kompetensi yang tinggi apabila pegawai tersebut memiliki pengalaman kerja, latar belakang pendidikan yang mendukung profesi, memiliki keahlian/pengetahuan dan memiliki keterampilan. Hasil observasi peneliti pada BMT Al-Ittihad diketahui bahwa memiliki kompetensi pegawai yang baik. Sebagaimana pegawai yang bekerja di BMT Al-Ittihad adalah pegawai yang telah berpengalaman, pendidikan pegawai minimal S1, pegawai diwajibkan menguasai/ mahir mengenai produk BMT Al-Ittihad dan menguasai pekerjaan yang di bebankan kepadanya, pihak BMT Al-Ittihad rutin melakukan pelatihan kepada para pegawai dan mengadakan evaluasi kerja.

Pada senin tanggal 2 Maret 2020, dinyatakan bahwa Covid-19 sudah masuk ke Indonesia. pengumuman resmi ini disampaikan oleh Presiden Joko Widodo bersama Menteri Kesehatan Terawan Agus Putranto. Pernyataan resmi dari World Health Organization (WHO) bahwa Corona Virus Disease-19 (COVID-19) atau Virus Corona sebagai pandemi global, maka siap atau tidak Indonesia harus menghadapi, mencegah dan melawan penyebaran Covid-19 tersebut. Untuk mencegah dan meminimalisir penyebaran virus corona di masyarakat, pemerintah telah melakukan berbagai upaya dan kebijakan, salah satunya adalah bekerja dari rumah atau Work From Home (WFH), yaitu melaksanakan tugas di rumah/tempat tinggalnya masing-masing.

Berdasarkan wawancara penulis dengan pegawai BMT Al-Ittihad, upaya untuk mencapai target yang telah ditetapkan tidak selamanya berjalan dengan lancar. Selama terjadinya pandemi COVID-19 sampai Era New Normal pegawai BMT Al-Ittihad tidak menerapkan sistem Work From Home (WFH), mereka tetap melakukan pekerjaan di kantor. BMT Al-Ittihad juga melayani nasabah seperti biasanya hanya saja pagawai menerapkan Physical distancing, membuat beberapa himbauan tentang COVID-19, adanya pagar pembatas antara pegawai dan nasabah, menyediakan cuci tangan dan mewajibkan penggunaan masker. Penulis juga mewawancarai pegawai BMT Al-Ittihad yang lain, mengatakan bahwa mereka telah melakukan banyak hal untuk tetap menarik minat nasabah seperti menjaga hubungan baik kepada para nasabah. Akan tetapi, banyak nasabah yang melakukan penangguhan pembayaran

${ }^{4}$ Wibowo, Manajemen Kinerja Edisi keempat, (Jakarta: PT RajaGrafindo Persada, 2014), hlm. 272-273. 
pembiayaan, melakukan penarikan tabungan dan pengunduran diri sebagai anggota. Hal ini menyebabkan tidak tercapai target yang telah ditetapkan oleh pihak BMT Al-Ittihad.

Adapun sebagai bahan rujukan bagi penulis pada penelitian ini yaitu, penelitian Muhamad Gulom, dalam penelitian ini mengacu pada lima indikator kompetensi yaitu motif, karakter, konsep diri, pengetahuan dan keterampilan. Dengan hasil bahwa secara simultan kompetensi berpengaruh signifikan terhadap mutu pelayanan pada Bank Pembangunan Daerah Kabupaten Tojo Una-Una. ${ }^{5}$ Kemudian penelitian Bentari dan Nuridin, dengan hasil bahwa terdapat hubungan positif dan signifikan antara kompetensi terhadap kinerja pegawai Bank Index Cabang Bekasi. ${ }^{6}$

Islam memiliki konsep dalam manajemen sumber daya insani bahwa setiap karyawan adalah manusia, karyawan tidak merupakan mesin dan tidak juga sebagai sumber bisnis serta menjadikan spiritualitas menjadi unsur pokok. Sadono Sukirno, dkk, mendefinisikan sumber daya insani (SDI) merupakan orang-orang dalam suatu organisasi yang memberikan sumbangan pemikiran dan melakukan berbagai jenis pekerjaan dalam mencapai tujuan organisasi. ${ }^{7}$

Sumber daya insani (SDI) yang bekerja di lingkungan suatu organisasi (personil, tenaga kerja, pegawai atau karyawan), potensi manusiawi merupakan penggerak organisasi dalam mewujudkan eksitensinya, fungsi dari potensi manusiawi adalah sebagai modal di dalam organisasi bisnis yang dapat diwujudkan menjadi potensi nyata secara fisik dan non fisik dalam eksitensi organisasi. ${ }^{8}$

Kompetensi adalah merupakan seperangkat tindakan cerdas, penuh tanggungjawab yang dimiliki seseorang sebagai syarat untuk dianggap mampu oleh masyarakat dalam melaksanakan tugas-tugasnya di bidang pekerjaan tertentu. ${ }^{9}$

Pengalaman kerja merupakan penguasaan pengetahuan dan keterampilan karyawan yang diukur dari lama masa kerja, tingkat

\footnotetext{
${ }^{5}$ Muhamad Gulom, Pengaruh Kompetensi, Disiplin dan Lingkungan Kerja Terhadap Mutu Pelayanan pada Bank Pembangunan Daerah Kabupaten Tojo Una-Una, (Jurnal Ekonomi, Vol.7 No.2, E-ISSN.2722-6565, 2019), hlm. 45. Diakses pada tanggal 13 Maret 2021.

${ }^{6}$ Bentari Faka dan Nuridin, Pengaruh Kompetensi dan Disiplin Kerja Terhadap Kinerja Pegawai Bank Index Cabang Bekasi, (Jurnal Manajemen Bisnis Krisnadwipayana, Vol.6 No.2, ISSN:2338-4794: UNKRIS Jakarta, 2018), hlm. 10. Diakses pada tanggal 13 Maret 2021.

${ }^{7}$ Sadono Sukirno, dkk, Pengantar Bisnis, (Jakarta: Kencana, 2011), hlm. 173.

8 Harsuko Riniwati, Manajemen Sumber Daya Manusia (Aktivitas Utama dan Pengembangan SDM), (Malang: UB Press, 2016), hlm. 1.

${ }^{9}$ Choirul Saleh, Pengembangan Kompetensi Sumber Daya Aparatur, (Malang: UB Press, 2013), hlm. 21.
} 
pengetahuan dan keterampilan yang dimiliki karyawan. Pengalaman hanya bisa didapatkan melalui tempat kerja. Nitisemito berpendapat dengan pengalaman kerja yang memadai akan membantu karyawan dalam menyelesaikan pekerjaan. Pengalaman kerja yang baik berdasarkan pada jangka waktu dalam menjalankan pekerjaan tersebut. ${ }^{10}$

Pendidikan adalah suatu proses, teknik, dan metode belajar mengajar dengan maksud mentransfer suatu pengetahuan dari seseorang kepada orang lain melalui prosedur yang sistematis dan terorganisasi yang berlangsung dalam jangka waktu yang relatif lama (Sedarmayanti, 2017). Pendidikan merupakan suatu indikator yang mencerminkan kemampuan seseorang untuk dapat menyelesaikan suatu pekerjaan. Dengan latar belakang pendidikan pula seseorang dianggap akan mampu menduduki suatu jabatan tertentu. ${ }^{11}$

Pengetahuan adalah kebiasaan, keahlian atau kepakaran, keterampilan, pemahaman atau pengertian yang diperoleh dari pengalaman, latihan atau melalui proses belajar atau bahkan keahlian yang diperoleh melalui usaha dan bakat tertentu seseorang. ${ }^{12}$

Keterampilan adalah keterampilan akutansi, kemampuan melayani para pelanggan, dan pengetahuan mengenai proses pekerjaan. Pegawai yang tidak memiliki keterampilan pekerjaan memerlukan pelatihan, supervisi ketat atau dipindahkan ke pekerjaan lainnya di mana ia mempunyai keterampilan untuk itu. ${ }^{13}$

Mutu pelayanan yang diberikan perusahaan tentunya tidaklah hanya bertujuan untuk memberikan kepuasan semata. Sebagai seorang muslim dalam memberikan pelayanan haruslah mendasarkan pada nilai-nilai syariah guna mewujudkan nilai ketaqwaan sekaligus membuktikan konsistensi keimanannya dalam rangka menjalankan nilai Syariat Islam. Dalam pandangan Islam yang dijadikan tolak ukur untuk menilai kualitas pelayanan

10 Andika Dwi Putra Pamungkas, dkk, Pengaruh Pendidikan dan Pengalaman Kerja Terhadap Kemampuan Kerja Dan Kinerja Karyawan (Studi pada Karyawan PT.INKA (Persero)), (Jurnal Administrasi Bisnis (JAB), Vol.43 No.1, 2017, Universitas Brawijaya Malang) ,hlm.98. Diakses pada tanggal 10 Agustus 2020. 2013), 54 .

${ }^{11}$ H.Melayu S.P. Hasibuan, Manajemen Sumber Daya Manusia, (Jakarta: PT Bumi Aksara,

12 Pawit M. Yusup, Perpektif Manajemen Pengetahuan Informasi, Komunikasi, Pendidikan dan Perpustakaan, (Jakarta: Rajawali Pres, 2012), hlm. 6.

13 Wirawan, Manajemen Sumber Daya Manusia Indonesia: Teori, Psikologi, Hukum Ketenagakerjaan, Aplikasi dan Penelitian: Aplikasi dalam Organisasi Bisnis, Pemerintah dan Pendidikan, Cet.1, 2015, hlm. 331. Diakses pada tanggal 22 Sepember 2020. 
terhadap konsumen yaitu standarisasi syariah. Oleh karena itu, variabelvariable yang diuji standar penilaian teori tersebut. ${ }^{14}$

Kinerja merupakan pelaksanaan fungsi-fungsi yang dituntut dari seseorang, yaitu keberhasilan yang paling minim yang menuntut kebutuhan tersebut. Dengan demikian, Whitmore mengemukakan bahwa kinerja yang dianggapnya representatif, maka akan tergambar tanggung jawab yang besar dari pekerjaan seseorang. ${ }^{15}$

Berdasarkan pernyataan dari Kementrian Kesehatan Indonesia, perkembangan kasus Covid-19 terjadi pada tanggal 30 Desember 2019, berawal dari Wuhan. World Health Organization (WHO) menyatakan bahwa Coronaviruses (Covid) adalah virus yang mengidenfikasi sistem pernapasan. Virus Corona yaitu zoonotic yang merupakan penularan dari manusia dan hewan. Sejak tanggal 2 Maret 2020, di Indonesia penyebaran Covid-19 diduga berawal dari salah seorang warga Indonesia yang berinteraksi secara langsung dengan warga asing yang berasal dari negara Jepang. Presiden Jokowi juga mengumumkan bahwa penyebaran Covid-19 telah mengalami peningkatan yang signifikan. ${ }^{16}$

\section{Metode}

Jenis penelitian ini ialah penelitian kuantitatif dengan menggunakan analisis jalur dengan model regresi linier berganda didukung dengan uji model dan uji statistik dengan menggunakan bantuan program SPSS versi 26. Adapun waktu dalam penelitian ini dilakukan pada saat pandemi COVID-19 sampai Era New Normal. Pada senin tanggal 2 Maret 2020, merupakan pengumuman resmi yang disampaikan Presiden Jokowi Widodo bersama Menteri Kesehatan Terawan Agus Putranto meyatakan bahwa Covid-19 sudah masuk ke Indonesia. Tempat penelitian ini dilakukan pada BMT Al-Ittihad di seluruh Indonesia. Populasi dalam penelitian ini adalah seluruh pegawai BMT AlIttihad berjumlah 30 orang. Adapun teknik pengambilan sampel dalam penelitian ini menggunakan metode total sampling, yaitu pengambilan sampel secara keseluruhan semua populasi dijadikan sampel. Sampel penelitian ini seluruh pegawai BMT Al-ittihad berjumlah 30 orang, maka seluruh populasi

14 Sari Rezeki Harahap, " Pengaruh Strategi Pengembangan Sumber Daya Insani Terhadap Peningkatan Kinerja Dan Mutu Pelayanan Pada Pt. Bank Muamalat Indonesia, Tbk Cabang Medan" , Tesis Magister, Sumatera Utara: UIN Sumatera Utara, 2016, hlm. 43.

15 Hamzah B.Uno dan Nina Lamatenggo, Teori Kinerja dan Pengukurannya, (Jakarta: Bumi Aksara, 2012), hlm. 60.

16 Silpa Hanoatubun, Dampak Covid-19 Terhadap Perekonomian Indonesia, Volume 2 Nomor 1 (2020) ISSN Online: 2716-4446, STKIP Muhammadiyah Enrekang, hlm. 147. Diakses pada tanggal 22 Oktober 2020. 
dijadikan sampel penelitian. Sedangkan untuk memperkuat data, maka dilakukan wawancara dengan nasabah. Teknik pengumpulan data dalam penelitian ini dilakukan dengan teknik observasi, wawancara, angket atau kuesioner dan dokumentasi. Teknis analisis data dalam penelitian ini dilakukan, yaitu:

\section{Analisis Deskriptif}

Analisis deskriptif berfungsi untuk mendeskripsikan atau memberi gambaran terhadap objek yang diteliti melalui data sampel atau populasi sebagaimana adanya, tanpa melakukan analisis dan membuat kesimpulan yang berlaku untuk umum (Sugiyono, 2010).

2. Uji Asumsi Klasik

Pengujian regresi linear berganda dapat dilakukan apabila model dari penelitian ini telah memenuhi syarat syarat yaitu lolos dari asumsi klasik. Untuk itu, sebelum melakukan regresi linear berganda, maka harus dilakukan pengujian asumsi klasik yang terdiri dari:

a. Uji Normalitas

Uji normalitas dilakukan dengan tujuan normal atau tidaknya data yang diperoleh dari hasil penelitian. Pada penelitian ini, uji normalitas data dilakukan dengan menggunakan program pengolah data SPSS 26 melalui uji normalitas one sample Kolmogrov-Smirnov. ${ }^{17}$

b. Uji Multikolinearitas

Uji multikolinearitas dapat diketahui dengan melakukan uji Variance Inflating Factor (VIF). Uji VIF merupakan salah satu metode pengujian yang mudah digunakan dalam menganalisis data apakah terjadi multikolinearitas atau tidak. Untuk melihat terjadinya gejala multikolinearitas dapat menilai nilai $\mathrm{t}$ dan nilai VIF apabila nilai $\mathrm{t}$ (toleransi) berada di atas $>0,10$ dan nilai VIF berada di bawah $<10$ maka dapat dikatakan bahwa tidak terjadi multikolinearitas diantara variabel yang diteliti dan sebaliknya. ${ }^{18}$

c. Uji Heterokedasitas

Uji Heterokedasitas bertujuan untuk menguji apakah dalam model regresi terjadi ketidaksamaan varian dari residual untuk semua

17 Rony Setiawan dan Nana Dara Priatna, Pengantar Statistik, (Yogyakarta: Graha Ilmu, 2005), hlm. 14.

18 Nikolaus Duli, Metodologi Penelitian Kuantitatif: Beberapa Konsep Dasar Untuk Penulisan Skripsi \& Analisis Data Dengan SPSS, (Yogyakarta: CV Budi Utama, 2019), hlm. 120. 
pengamatan pada model regresi. Pola yang tidak sama ini ditunjukkan dengan nilai yang tidak sama antar varians dari residual.

d. Uji Autokolerasi

Uji autokolerasi digunakan untuk mengetahui ada atau tidaknya penyimpangan asumsi klasik autokolerasi yaitu kolerasi yang terjadi antara residual pada satu pengamatan dengan pengamatan lain pada model regresi. ${ }^{19}$

3. Uji Regresi

Metode yang digunakan untuk menguji hipotesis satu sampai sembilan dengan analisis regresi berganda. Hipotesis pertama sampai sembilan diuji dengan menentukan tingkat signifikansi dengan uji simultan (Uji $F_{\text {test dan }} \mathrm{R}^{2}$ ) dan uji parsial (Uji t-test) sebagai berikut:

a. Uji Determinasi $\left(\mathrm{R}^{2}\right)$

Uji determinasi digunakan untuk mengukur sejauh mana kemampuan model dalam menerangkan variasi variabel dependen. Nilai koefisien determinasi adalah di antara nol dan satu. Nilai yang mendekati satu variabel-variabel independen memberikan hampir semua informasi yang dibutuhkan untuk memprediksi variasi variabel dependen.

b. Uji F-test

Pedoman yang digunakan untuk manerima atau menolak hipotesis yaitu:

- Ha diterima jika F-hitung>F-tebel, atau nilai p-value pada kolom sig.<level of significant $(\alpha) 5 \%$ berarti seluruh variabel independen secara bersama-sama mempengaruhi variabel dependen.

- Ho diterima jika F-hitung < F-tabel, atau nilai p-value pada kolom sig.>level of significant $(\alpha) 5 \%$ berarti seluruh variabel independen tidak secara bersama-sama mempengaruhi variabel dependen.

c. Uji $t$-tes

Untuk mengetahui signifikansi atau tidaknya koefisien regresi secara parsial, maka digunakan uji t untuk pengujiannya. Caranya sebagai berikut:

- Jika t-tabel < t-hitung, maka Ho diterima.

- Jika t-tabel > t-hitung, maka Ho ditolak.

Berdasarkan nilai signifikansi:

- Jika signifikansi >0,05 maka Ho diterima.

- Jika signifikansi < 0,05 maka Ho ditolak.

d. Analisis Jalur (Path Analysis)

${ }^{19}$ Agus Tri Basuki dan Nano Prawoto, Analisis Regresi dalam Penelitian Ekonomi dan Bisnis, (Jakarta: RajaGrafindo Persada, 2017), hlm. 60. 
Analisis jalur merupakan pengembangan dari analisis regresi linear berganda. Analisis jalur menguji persamaan regresi yang melibatkan beberapa variabel exogen dan endogen sekaligus sehingga memungkinkan pengujian terhadap variabel mediating / intervening atau variabel antara. Disamping itu analisis jalur bisa mengukur hubungan langsung dan tidak langsung antar variabel. Untuk menguji pengaruh variabel intervening, digunakan metode analisis jalur.

e. Uji Sobel

Uji sobel adalah uji yang digunakan untuk mengetahui pengaruh variabel antara (intervening) yaitu mutu pelayanan. Suau variabel disebut intervening apabila variabel tersebut mempengaruhi hubungan antara variabel independen dan variabel dependen. ${ }^{20}$

$$
\mathrm{Z}=\frac{\mathrm{ab}}{\sqrt{ } b^{2} S E a^{2}+\alpha^{2} \mathrm{SE}_{\mathrm{b}}^{2}}
$$

\section{Hipotesis Penelitian}

1. H1a: Ada pengaruh pengalaman kerja terhadap mutu pelayanan

2. H2a: Ada pengaruh pendidikan terhadap mutu pelayanan

3. H3a: Ada pengaruh pengetahuan terhadap mutu pelayanan

4. H4a : Ada pengaruh keterampilan terhadap mutu pelayanan

5. H1b : Ada pengaruh pengalaman kerja terhadap kinerja

6. $\mathrm{H} 2 \mathrm{~b}$ : Ada pengaruh pendidikan terhadap kinerja

7. H3b : Ada pengaruh pengetahuan terhadap kinerja

8. H4b : Ada pengaruh keterampilan terhadap kinerja

9. H5 : Ada pengaruh mutu pelayanan terhadap kinerja

\section{Hasil dan Pembahasan \\ Uji Normalitas}

Pengujian normalitas bertujuan untuk mengetahui pola distribusi dari suatu data hasil penelitian. Hal ini merupakan salah satu syarat untuk melakukan analisis regresi linier berganda. Uji normalitas dapat dilihat dari kurva Histogram dan grafik Normal $p$-plot, sebagai berikut:

${ }^{20}$ Imam Ghazali, Aplikasi Analisis Multivariate dengan Program IBM SPSS, (Yogyakarta: Universitas Diponegoro, 2013), hlm.87. 
Gambar.1

Kurva Histogram 1

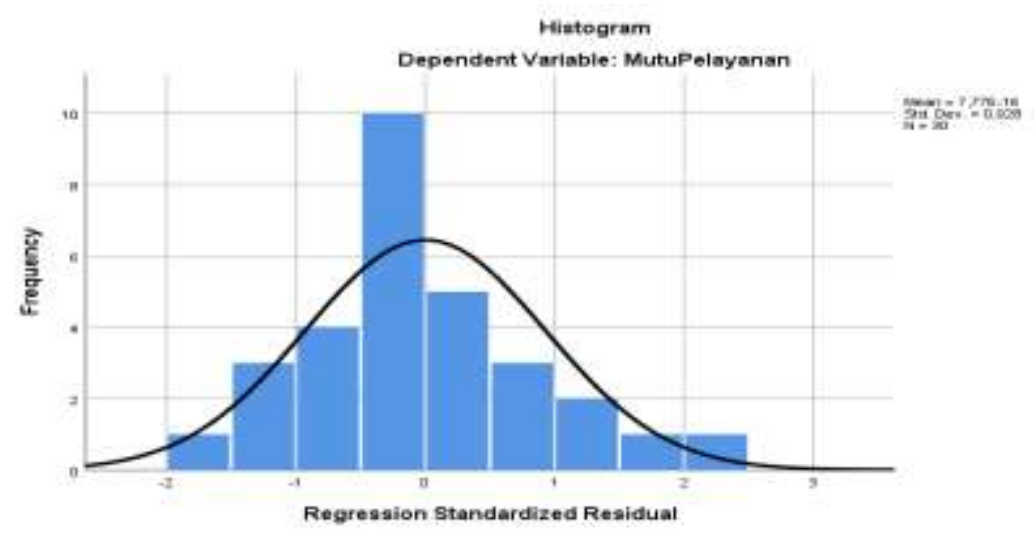

Gambar.2

Kurva Histogram 2

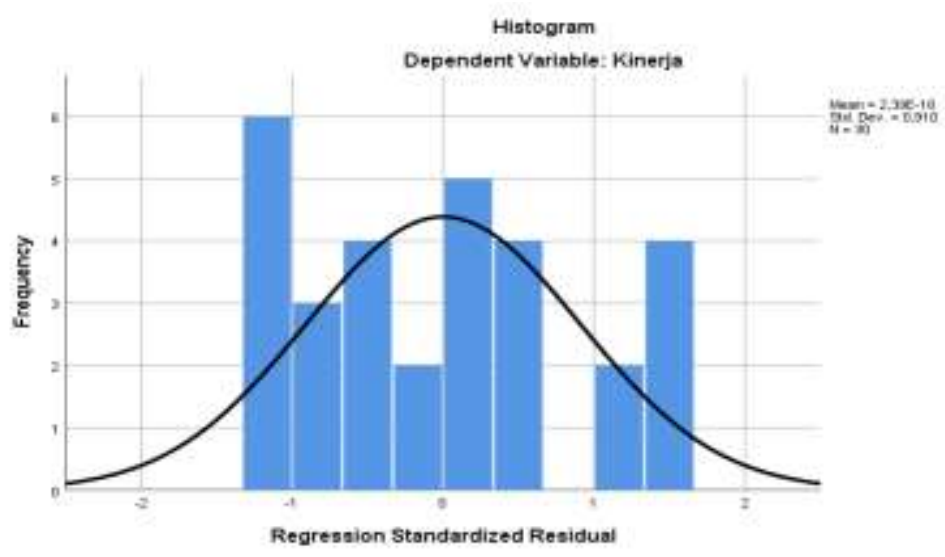

Sumber: Olah Data SPSS versi. 26.0

Berdasarkan Gambar 1 dan 2 dapat dilihat bahwa kurva tidak condong ke kanan dan ke kiri, melainkan tepat berada di tengah. Hal ini dapat disimpulkan bahwa semua variabel dalam penelitian ini tidak memiliki variabel penggagu yang mengakibatkan data tidak berdistribusi normal.

\section{Uji Multikolinearitas}

Uji multikolinearitas dapat diketahui dengan melakukan uji Variance Inflating Factor (VIF). Untuk melihat terjadinya gejala multikolinearitas dapat dilihat dari nilai t dan nilai VIF apabila nilai t (toleransi) berada diatas 0,10 dan nilai VIF berada di bawah 10 maka dapat dikatakan bahwa tidak terjadi multikolinearitas. Hasil terlihat pada tabel dibawah ini: 
Tabel.8

Hasil Uji Multikolinearitas

\begin{tabular}{|l|l|c|c|}
\hline \multicolumn{3}{|c|}{ Coefficient Correlations } \\
\hline \multirow{2}{*}{ Model } & \multicolumn{2}{c|}{ Collinearity Statistics } \\
\cline { 3 - 4 } & \multirow{2}{*}{1} & Tolerance & VIF \\
\hline \multirow{3}{*}{1} & Pengalaman Kerja & 0,751 & 1,331 \\
\cline { 2 - 4 } & Pendidikan & 0,518 & 1,930 \\
\cline { 2 - 4 } & Pengetahuan & 0,720 & 1,389 \\
\cline { 2 - 4 } & Keterampilan & 0,511 & 1,956 \\
\cline { 2 - 4 } & Mutu Pelayanan & 0,344 & 2,904 \\
\hline \multirow{2}{*}{ a. Dependen Variabel: Kinerja } & & \\
\hline
\end{tabular}

Sumber: Olah Data SPSS versi. 26.0

Berdasarkan Tabel.8 diatas terlihat bahwa nilai tolerance dari variabel pengalaman kerja sebanyak $1,331<10$, variabel pendidikan dengan nilai $1,930<10$, variabel pengetahuan dengan nilai 1,389 , variabel keterampilan dengan nilai $1,956<10$, dan variabel mutu pelayanan dengan nilai $2,904<10$. Nilai tolerance masing-masing variabel berada diatas 0,10 dan nilai VIF seluruh variabel berada di bawah 10. Maka kesimpulannya tidak ada multikolinearitas, karena nilai tolerance $>0,10$ atau nilai $\mathrm{VIF}<10$.

\section{Uji Heterokedasitas}

Model regresi yang baik adalah yang tidak terjadi heterokedasitas. Uji heterokedasitas dilakukan agar suatu persamaan regresi tidak bias. Untuk mengetahui terjadi atau tidaknya heterokedasitas dapat dilihat dari grafik pancar residual. Dimana jika di dalam terjadi heterokedasitas. Untuk mengetahui hal tersebut dapat dilihat melalui gambar 5 dan 6.

\section{Gambar 5}

\section{Hasil Uji Heterokedasitas 1}

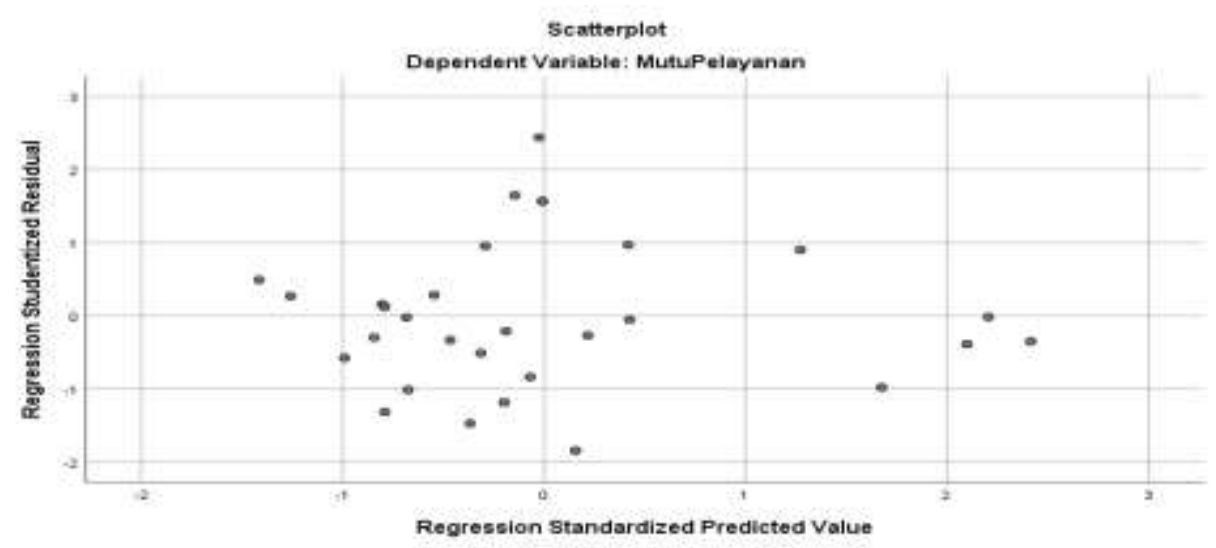




\section{Gambar.6}

\section{Hasil Uji Heterokedasitas 2}

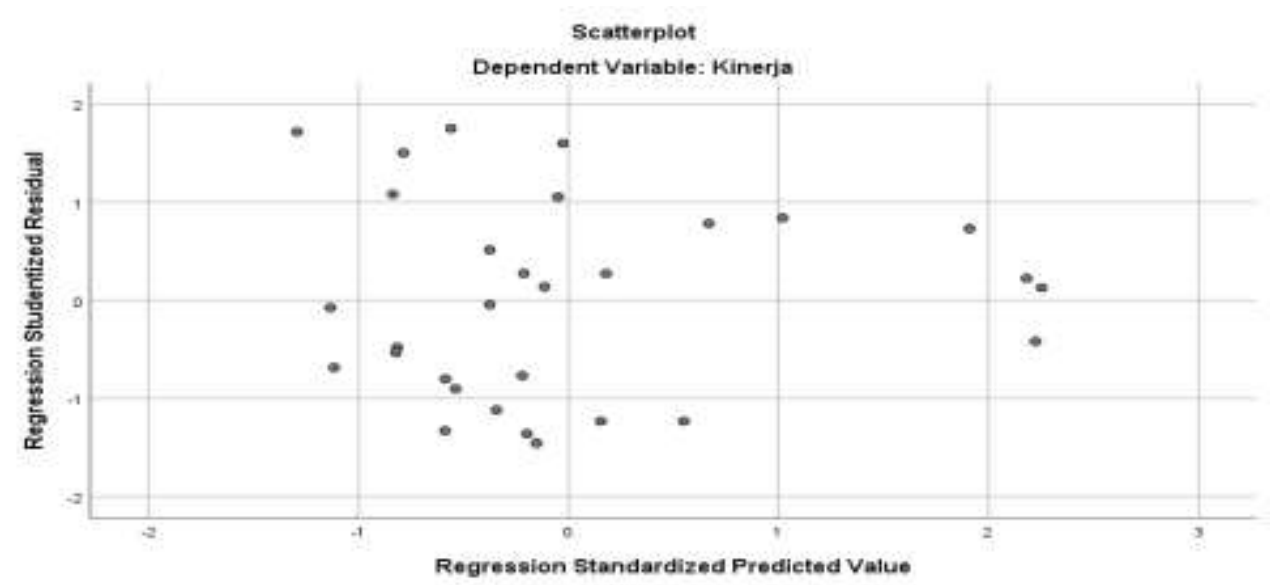

Sumber: Olah Data SPSS versi. 26.0

Berdasarkan gambar 5 dan 6 diatas terlihat grafik pancar residual memang tidak membentuk pola tertentu. Jadi dapat dikatakan bahwa tidak terdeteksi heteroskedastisitas.

\section{Uji Autokolerasi}

Uji autokolerasi digunakan untuk mengetahui ada atau tidaknya penyimpangan asumsi klasik autokolerasi yaitu kolerasi yang terjadi antara residual pada satu pengamatan dengan pengamatan lain pada model regresi. Uji ini dianalisis melalui uji Durbin-Watson dengan ketentuan atau dasar pengambilan keputusan, jika Durbin-Watson terletak antara du dan (4-du), sebagai berikut:

Tabel. 9

Hasil Uji Autokolerasi

\begin{tabular}{|c|c|c|c|c|c|}
\hline \multicolumn{6}{|c|}{ Model Summary } \\
\hline Model & $\mathrm{R}$ & R Square & $\begin{array}{l}\text { Adjusted R } \\
\text { Square }\end{array}$ & $\begin{array}{l}\text { Std. Error } \\
\text { of the } \\
\text { Estimate }\end{array}$ & $\begin{array}{l}\text { Durbin- } \\
\text { Watson }\end{array}$ \\
\hline 1 &, $786^{\mathrm{a}}$ & 0,618 & 0,538 & 0,04918 & 1,512 \\
\hline \multicolumn{6}{|c|}{$\begin{array}{l}\text { a. Predictors: (Constant), LnMutuPelayanan, LnPengalamankerja, } \\
\text { LnPengetahuan, LnKeterampilan, LnPendidikan }\end{array}$} \\
\hline
\end{tabular}

Sumber: Olah Data SPSS versi. 26.0

Terlihat pada tabel.9 diatas bahwa nilai Durbin-Watson yang dihasilkan adalah 1,512. Sedangkan dari nilai tabel Durbin-Watson diperoleh nilai du sebesar 1,071, nilai dw sebesar 1,512 dan nilai (4-du) sebesar 2,929. Maka 
dapat disimpulkan bahwa tidak terdapat gejala autokorelasi, sehingga analisis regresi dapat dilanjutkan.

\section{Uji Regresi Linier Berganda}

\section{Hasil Uji t}

Maka dapat dilihat hasil pengujian nilai t hitung menggunakan SPSS.26, sebagai berikut:

Tabel. 10

Hasil Uji t Hitung 1

\begin{tabular}{|c|c|c|c|c|c|c|}
\hline \multicolumn{7}{|c|}{ Coefficients ${ }^{a}$} \\
\hline \multirow{2}{*}{\multicolumn{2}{|c|}{ Model }} & \multicolumn{2}{|c|}{$\begin{array}{l}\text { Unstandardized } \\
\text { Coefficients }\end{array}$} & \multirow{2}{*}{$\begin{array}{c}\text { Standardized } \\
\text { Coefficients } \\
\text { Beta } \\
\end{array}$} & \multirow[b]{2}{*}{$\mathrm{t}$} & \multirow[b]{2}{*}{ Sig. } \\
\hline & & B & $\begin{array}{l}\text { Std. } \\
\text { Error }\end{array}$ & & & \\
\hline \multirow[t]{5}{*}{1} & (Constant) & $-17,930$ & 8,884 & & $-2,018$ & 0,054 \\
\hline & PengalamanKerja & 0,530 & 0,225 & 0,288 & 2,350 & 0,027 \\
\hline & Pendidikan & 0,554 & 0,245 & 0,335 & 2,258 & 0,033 \\
\hline & Pengetahuan & 0,431 & 0,158 & 0,331 & 2,722 & 0,012 \\
\hline & Keterampilan & 0,566 & 0,238 & 0,353 & 2,379 & 0,025 \\
\hline
\end{tabular}

Sumber: Olah Data SPSS versi. 26.0

Tabel. 11

Hasil Uji t Hitung 2

\begin{tabular}{|c|c|c|c|c|c|c|}
\hline \multicolumn{7}{|c|}{ Coefficients $^{a}$} \\
\hline \multirow{2}{*}{\multicolumn{2}{|c|}{ Model }} & \multicolumn{2}{|c|}{$\begin{array}{l}\text { Unstandardized } \\
\text { Coefficients }\end{array}$} & \multirow{2}{*}{$\begin{array}{c}\text { Standardized } \\
\text { Coefficients } \\
\text { Beta }\end{array}$} & \multirow[t]{2}{*}{$\mathrm{t}$} & \multirow[t]{2}{*}{ Sig. } \\
\hline & & B & $\begin{array}{l}\text { Std. } \\
\text { Error }\end{array}$ & & & \\
\hline \multirow[t]{6}{*}{1} & (Constant) & $-10,185$ & 9,184 & & $-1,109$ & 0,278 \\
\hline & PengalamanKerja & 0,599 & 0,239 & 0,351 & 2,510 & 0,019 \\
\hline & Pendidikan & 0,729 & 0,258 & 0,476 & 2,826 & 0,009 \\
\hline & Pengetahuan & 0,404 & 0,173 & 0,334 & 2,338 & 0,028 \\
\hline & Keterampilan & 0,832 & 0,252 & 0,559 & 3,297 & 0,003 \\
\hline & MutuPelayanan & $-0,402$ & 0,192 & $-0,433$ & $-2,096$ & 0,047 \\
\hline
\end{tabular}

Sumber: Olah Data SPSS versi. 26.0 


\section{Hasil Uji F}

Maka dapat dilihat hasil pengujian nilai F hitung menggunakan SPSS.26, sebagai berikut:

Tabel. 12

Hasil Uji Simultan (uji F) 1

\begin{tabular}{|c|c|c|c|c|c|c|}
\hline \multicolumn{7}{|c|}{ ANOVAa } \\
\hline \multicolumn{2}{|c|}{ Model } & Sum of Squares & $\mathrm{df}$ & $\begin{array}{l}\text { Mean } \\
\text { Sauare }\end{array}$ & $\mathrm{F}$ & Sig. \\
\hline \multirow[t]{3}{*}{1} & Regression & 221,527 & 4 & 55,382 & 11,901 & $000^{\mathrm{b}}$ \\
\hline & Residual & 116,340 & 25 & 4,654 & & \\
\hline & Total & 337,867 & 29 & & & \\
\hline \multicolumn{7}{|c|}{ a. Dependent Variable: MutuPelayanan } \\
\hline \multicolumn{7}{|c|}{$\begin{array}{l}\text { b. Predictors: (Constant), Keterampilan, PengalamanKerja, Pengetahuan, } \\
\text { Pendidikan }\end{array}$} \\
\hline
\end{tabular}

Sumber: Olah Data SPSS versi. 26.0

Tabel. 13

Hasil Uji F Hitung 2

\begin{tabular}{|c|c|c|c|c|c|c|}
\hline \multicolumn{7}{|c|}{ ANOVA $^{a}$} \\
\hline \multicolumn{2}{|c|}{ Model } & & & Mean & & \\
\hline \multirow[t]{3}{*}{1} & Regression & 188,343 & 5 & 37,669 & 8,809 &, $000^{\mathrm{b}}$ \\
\hline & Residual & 102,624 & 24 & 4,276 & & \\
\hline & Total & 290,967 & 29 & & & \\
\hline \multicolumn{7}{|c|}{ a. Dependent Variable: Kinerja } \\
\hline \multicolumn{7}{|c|}{$\begin{array}{l}\text { b. Predictors: (Constant), MutuPelayanan, PengalamanKerja, Pengetahuan, } \\
\text { Pendidikan, Keterampilan }\end{array}$} \\
\hline
\end{tabular}

Sumber: Olah Data SPSS versi. 26.0

\section{Hasil Uji (Determinasi)R ${ }^{2}$}

Maka dapat dilihat hasil pengujian nilai determinasi $\left(\mathrm{R}^{2}\right)$ menggunakan SPSS.26, sebagai berikut:

Tabel. 14

Hasil Uji Determinasi $\left(R^{2}\right) 1$

\begin{tabular}{|c|c|c|c|c|}
\hline \multicolumn{5}{|c|}{ Model Summary } \\
\hline Model & $\mathrm{R}$ & R Square & Adjusted R Square & Std. Error of the Estimate \\
\hline 1 &, $810 \mathrm{a}$ & 0,656 & 0,601 & 2,15722 \\
\hline $\begin{array}{l}\text { a Predictors: (Constant), Keterampilan, PengalamanKerja, Pengetahuan, } \\
\text { Pendidikan }\end{array}$ \\
\hline
\end{tabular}

Sumber: Olah Data SPSS versi. 26.0 
Tabel. 15

Hasil Uji Determinasi $\left(R^{2}\right) 2$

\begin{tabular}{|c|c|c|c|c|}
\hline \multicolumn{5}{|c|}{ Model Summary } \\
\hline Model & $\mathrm{R}$ & R Square & Adjusted R Square & Std. Error of the Estimate \\
\hline 1 &, $805 \mathrm{a}$ & 0,647 & 0,574 & 2,06785 \\
\hline $\begin{array}{l}\text { a Predictors: (Constant), MutuPelayanan, PengalamanKerja, Pengetahuan, } \\
\text { Pendidikan, Keterampilan }\end{array}$
\end{tabular}

Sumber: Olah Data SPSS versi. 26.0

\section{Pembahasan}

\section{Pengaruh Pengalaman Kerja terhadap Mutu Pelayanan pada BMT Al-} Ittihad selama era new normal

Berdasarkan output SPSS.26, hasil penelitian ini menunjukkan bahwa nilai t hitung variabel pengalaman kerja yaitu 2,350 dan t tabel yang diperoleh sebanyak 2,048. Jadi t hitung $>$ t tabel $(2,350>2,048)$, dengan nilai sig sebanyak $0,027(0,027<0,05)$, maka $\mathrm{H}_{0}$ ditolak dan Ha diterima, sehingga dapat dinyatakan bahwa variabel pengalaman kerja berpengaruh positif dan signifikan terhadap mutu pelayanan pada BMT Al-Ittihad selama era new normal.

Hasil ini didukung dengan penelitian yang dilakukan oleh Matdio Siahaan dan Hema Sianturi, menunjukkan bahwa variabel pengalaman kerja memiliki pengaruh positif dan signifikan terhadap kualitas pelayanan pajak, maka dalam hal ini pegawai pajak perlu mempertahankan dan meningkatkan dalam pelayanannya agar pelanggan tetap merasa puas terhadap kinerja dari pegawai.

2. Pengaruh Pendidikan terhadap Mutu Pelayanan pada BMT Al-Ittihad selama era new normal

Berdasarkan output SPSS.26, hasil penelitian ini menunjukkan bahwa nilai t hitung variabel pendidikan yaitu 2,258 dan t tabel yang diperoleh sebanyak 2,048. Jadi t hitung >t tabel, $(2,258>2,048)$, dengan nilai sig sebanyak $0,033(0,033<0,05)$, maka Ho ditolak dan Ha diterima, sehingga dapat dinyatakan bahwa variabel pendidikan berpengaruh positif dan signifikan terhadap mutu pelayanan pada BMT Al-Ittihad selama era new normal.

Hasil ini didukung dengan penelitian yang dilakukan oleh Abi Muhlisin, dkk, menunjukkan bahwa hasil penelitian diketahui hasil analisis uji Chi-Square diperoleh nilai p-value 0,008 dimana tingkat signifikansi kurang dari 0,05. Hasil tersebut membuktikan bahwa memang ada 
hubungan yang signifikan antara tingkat pendidikan dengan persepsi pasien tentang mutu pelayanan kesehatan di Puskesmas Baki.

3. Pengaruh Pengetahuan terhadap Mutu Pelayanan pada BMT AlIttihad selama era new normal

Berdasarkan output SPSS.26, hasil penelitian ini menunjukkan bahwa nilai t hitung variabel pengetahuan yaitu 2,722 dan t tabel yang diperoleh sebanyak 2,048. Jadi $t$ hitung $>$ t tabel $(2,722>2,048)$, dengan nilai sig sebanyak $0,012(0,012<0,05)$, maka Ho ditolak dan Ha diterima, sehingga dapat dinyatakan bahwa variabel pengetahuan berpengaruh positif dan signifikan terhadap mutu pelayanan pada BMT Al-Ittihad selama era new normal.

Hasil ini didukung dengan penelitian yang dilakukan oleh Anasril dan Muhammad Husaini, menunjukkan bahwa hasil penelitian terdapat hubungan pengetahuan dengan mutu pelayanan pada Puskesmas Cot Seumeureung Kecamatan Samatiga Kabupaten Aceh Barat. Artinya terdapat hubungan antara tingkat pengetahuan dengan mutu pelayanan.

4. Pengaruh Keterampilan terhadap Mutu Pelayanan pada BMT AlIttihad selama era new normal

Berdasarkan output SPSS.26, hasil penelitian ini menunjukkan bahwa nilai t hitung variabel keterampilan yaitu 2,379 dan t tabel yang diperoleh sebanyak 2,048. Jadi $t$ hitung $>t$ tabel $(2,379>2,048)$, dengan nilai sig sebanyak 0,025 $(0,025<0,05)$, maka Ho ditolak dan Ha diterima, sehingga dapat dinyatakan bahwa variabel keterampilan berpengaruh positif dan signifikan terhadap mutu pelayanan pada BMT Al-Ittihad selama era new normal.

Hasil ini didukung dengan penelitian yang dilakukan Desi Arief Setiani, dkk, hasil bahwa penelitian ini terdapat pengaruh yang positif dan signifikan secara simultan keterampilan terhadap mutu layanan.

\section{Pengaruh Pengalaman Kerja terhadap Kinerja pada BMT Al-Ittihad selama era new normal}

Berdasarkan output SPSS.26, hasil penelitian ini menunjukkan bahwa nilai $\mathrm{t}$ hitung variabel pengalaman kerja yaitu 2,510 dan t tabel yang diperoleh sebanyak 2,048 . Jadi t hitung $>t$ tabel $(2,510>2,048)$, dengan nilai sig sebanyak 0,019 $(0,019<0,05)$, maka Ho ditolak dan Ha diterima, sehingga dapat dinyatakan bahwa variabel pengalaman kerja berpengaruh positif dan signifikan terhadap kinerja pada BMT Al-Ittihad selama era new normal. 
Hasil ini didukung dengan penelitian yang dilakukan oleh Vicki Anggreini dan Agus Hermani DS, hasil penelitian ini menunjukkan bahwa variabel pengalaman kerja memiliki pengaruh yang signifikan, kuat dan positif terhadap kinerja karyawan. Hal ini sejalan juga dengan penelitian yang dilakukan oleh Yananda Nurul Budi Atmiranti, dkk hasil penelitian ini menunjukkan bahwa ada pengaruh yang signifikan antara keseluruhan variabel bebas (Pengembangan Karir, Pengalaman Kerja dan Keterlibatan Kerja) secara simultan berpengaruh terhadap Kinerja Karyawan.

\section{Pengaruh Pendidikan terhadap Kinerja pada BMT Al-Ittihad selama era new normal}

Berdasarkan output SPSS.26, hasil penelitian ini menunjukkan bahwa nilai t hitung variabel pendidikan yaitu 2,826 dan $\mathrm{t}$ tabel yang diperoleh sebanyak 2,048. Jadi $t$ hitung $>$ t tabel $(2,826>2,048)$, dengan nilai sig sebanyak 0,009 $(0,009<0,05)$, maka Ho ditolak dan Ha diterima, sehingga dapat dinyatakan bahwa variabel pendidikan berpengaruh positif dan signifikan terhadap kinerja pada BMT Al-Ittihad selama era new normal.

Hasil ini didukung dengan penelitian yang dilakukan oleh Juliana, dkk, hasil penelitian menunjukkan bahwa ada pengaruh yang signifikan antara tingkat pendidikan terhadap kinerja pegawai di Badan Perencanaan Pembangunan Daerah Kabupaten Enrekang. Penelitian juga didukung oleh hasil penelitian Wayan Bagia, dkk, berdasarkan hasil penelitian menunjukkan bahwa ada pengaruh tingkat pendidikan dan pengalaman kerja terhada kinerja karyawan pada PT Mandiri Cabang Singaraja. Hasil penelitian ini mendukung teori yang dikemukakan oleh Usman, bahwa semakin tinggi tingkat pendidikan dan pengalaman kerja maka akan semakin tinggi kinerja yang ditampilkan karyawan.

\section{Pengaruh Pengetahuan terhadap Kinerja pada BMT Al-Ittihad selama era new normal}

Berdasarkan output SPSS.26, hasil penelitian ini menunjukkan bahwa nilai $t$ hitung variabel pengetahuan yaitu 2,338 dan $\mathrm{t}$ tabel yang diperoleh sebanyak 2,048. Jadi $t$ hitung>t tabel $(2,338>2,048)$, dengan nilai sig sebanyak $0,028(0,028<0,05)$, maka Ho ditolak dan Ha diterima, sehingga dapat dinyatakan bahwa variabel pengetahuan berpengaruh positif dan signifikan terhadap kinerja pada BMT Al-Ittihad selama era new normal.

Hasil ini didukung dengan penelitian yang dilakukan oleh Mazdayani, dkk, hasil penelitian menunjukkan bahwa pengetahuan, keterampilan, motivasi dan kompensasi berpengaruh terhadap kinerja mandor sadap. Sedangkan pengetahuan, keterampilan, dan motivasi berpengaruh 
terhadap kinerja mandor sadap di PT Perkebunan Nusantara VII, Unit Bisnis Kedaton dan Unit Bisnis Way Berulu sebagian. Penelitian juga dilakukan oleh Alias dan Serlin Serang, berdasarkan hasil pengujian menunjukkan bahwa pengetahuan berpengaruh positif dan signifikan terhadap kinerja karyawan pada Kantor BPJS Ketenagakerjaan Cabang Makassar.

\section{Pengaruh Keterampilan terhadap Kinerja pada BMT Al-Ittihad selama} era new normal

Berdasarkan output SPSS.26, hasil penelitian ini menunjukkan bahwa nilai t hitung variabel keterampilan yaitu 3,297 dan t tabel yang diperoleh sebanyak 2,048. Jadi t hitung $>$ t tabel $(3,297>2,048)$, dengan nilai sig sebanyak 0,003 $(0,003<0,05)$, maka $\mathrm{H}_{0}$ ditolak dan Ha diterima, sehingga dapat dinyatakan bahwa variabel keterampilan berpengaruh positif dan signifikan terhadap kinerja pada BMT Al-Ittihad selama era new normal.

Hasil ini didukung dengan penelitian yang dilakukan oleh Abdul Latief, dkk, hasil penelitian ini menunjukkan bahwa variabel keterampilan berpengaruh signifikan terhadap variabel kinerja karyawan pada Kantor Pusat PT. Perkebunan Nusantara I Langsa. Selain itu, penelitian juga dilakukan oleh Tettie Setiyarti, dkk, (2020), berdasarkan hasil pengujian menunjukkan bahwa keterampilan berpengaruh positif dan signifikan terhadap kinerja karyawan di Hotel Panorama Ubud.

9. Pengaruh Mutu Pelayanan terhadap Kinerja pada BMT Al-Ittihad selama era new normal

Berdasarkan output SPSS.26, hasil penelitian ini menunjukkan bahwa nilai $\mathrm{t}$ hitung variabel mutu pelayanan yaitu $-2,096$ dan $\mathrm{t}$ tabel yang diperoleh sebanyak 2,048. Jadi thitung $<$ t tabel $(-2,096<2,048)$, dengan nilai sig sebanyak 0,047 $(0,047<0,05)$, maka Ho ditolak dan Ha diterima, sehingga dapat dinyatakan bahwa variabel mutu pelayanan berpengaruh negatif dan signifikan terhadap kinerja pada BMT Al-Ittihad selama era new normal.

Hasil ini sejalan dengan penelitian yang dilakukan oleh Nova Hari Santhi dan Widya Hartati, yang menunjukkan terdapat pengaruh yang signifikan antara kualitas pelayanan terhadap kinerja karyawan.

\section{Kesimpulan}

Berdasarkan analisis dan pembahasan dapat ditarik kesimpulan sebagai berikut.

1. Secara simultan terdapat pengaruh yang positif dan signifikan antara kompetensi terhadap mutu pelayanan. Hal ini dapat dibuktikan melalui uji F diperoleh nilai F-hitung sebanyak 11,901 dan F-tabel yang diperoleh 
sebanyak 2,74 dengan nilai signifikansi 0,000<0,05. Jadi $\mathrm{F}$ hitung $>\mathrm{F}$ tabel $(11,901>2,74)$, maka $H_{0}$ ditolak. Nilai signifikansi $F$ adalah 0,000 karena nilai sig $\mathrm{F}<0,05$, maka Ho ditolak dan Ha diterima. Hal ini mengandung arti bahwa variabel pengalaman kerja, pendidikan, pengetahuan dan keterampilan secara bersama-sama mempunyai pengaruh yang signifikan terhadap mutu pelayanan pada BMT Al-Ittihad selama era new normal.

2. Secara simultan terdapat pengaruh yang positif dan signifikan antara kompetensi terhadap kinerja. Hal ini dapat dibuktikan melalui uji $\mathrm{F}$ diperoleh nilai F-hitung sebanyak 8,809 dan F-tabel yang diperoleh sebanyak 2,74 dengan nilai signifikansi $0,000<0,05$, maka Ho ditolak. Nilai signifikansi $\mathrm{F}$ adalah 0,000 karena nilai sig $\mathrm{F}<0,05$, maka Ho ditolak dan $\mathrm{Ha}$ diterima. Hal ini mengandung arti bahwa variabel pengalaman kerja, pendidikan, pengetahuan, keterampilan dan mutu pelayanan secara bersama-sama mempunyai pengaruh yang signifikan terhadap kinerja pada BMT Al-Ittihad selama era new normal.

3. Hasil analisis regresi uji determinasi pada kompetensi terhadap mutu pelayanan sebanyak 0,656. Hal ini mengandung arti bahwa pengaruh variabel pengalaman kerja, pendidikan, pengetahuan dan keterampilan terhadap mutu pelayanan pada BMT Al-Ittihad selama era new normal adalah sebesar $65,6 \%$ sedangkan sisanya $34,4 \%$ dijelaskan oleh pengaruh faktor-faktor lain.

4. Hasil analisis regresi uji determinasi pada kompetensi terhadap kinerja sebanyak 0,647. Hal ini mengandung arti bahwa pengaruh variabel pengalaman kerja, pendidikan, pengetahuan, keterampilan dan mutu pelayanan terhadap kinerja pada BMT Al-Ittihad selama era new normal adalah sebesar $64,7 \%$ sedangkan sisanya 35,3\% dijelaskan oleh pengaruh faktor-faktor lain.

\section{Daftar Pustaka}

Agus Tri Basuki dan Nano Prawoto. 2017. Analisis Regresi dalam Penelitian Ekonomi dan Bisnis. Jakarta: RajaGrafindo Persada.

Ahmad Mujahidin. 2007. Ekonomi Islam. Jakarta: PT.RajaGrafindo.

Anwar Prabu Mangkunegara. 2001. Manajemen Sumber Daya Manusia Perusahaan. Bandung: Remaja Rosdakaya.

Bentari Faka dan Nuridin. 2018. Pengaruh Kompetensi dan Disiplin Kerja Terhadap Kinerja Pegawai Bank Index Cabang Bekasi. Jurnal Manajemen Bisnis Krisnadwipayana, Vol.6 No.2, ISSN:2338-4794: UNKRIS Jakarta. Diakses pada tanggal 13 Maret 2021.

Choirul Saleh. 2013. Pengembangan Kompetensi Sumber Daya Aparatur. Malang:UB Press. 
Harsuko Riniwati. (2016). Manajemen Sumber Daya Manusia (Aktivitas Utama dan Pengembangan SDM). Malang: UB Pres.

Henry Hartanti. (2018). Pengaruh Kompetensi, Disiplin Kerja, Pendidikan dan Pelatihan Terhadap Kinerja Pegawai pada Dinas Perdagangan Bantul. STIE Widya Wiwaha Yogyakarta.

Imam Ghazali. (2013). Aplikasi Analisis Multivariate dengan Program IBM SPSS. Yogyakarta: Universitas Diponogoro.

Nikolaus Duli. 2019. Metodologi Penelitian Kuantitatif: Beberapa Konsep Dasar Untuk Penulisan Skripsi \& Analisis Data Dengan SPSS. Yogyakarta: CV Budi Utama.

Nur Aini dan Miftahulhidayah Sudirman. (2019). Pengaruh Pengetahuan, Kemampuan dan Pengalaman Kerja Terhadap Kinerja Karyawan di Bank Rakyat Indonesia Syariah Kantor Cabang Bandung Suniaraja, Jurnal Perbankan Syariah, STIBANKS Al-M a'soem.

Malayu S.P. Hasibuan. (2013). Manajemen Sumber Daya Manusia. Jakarta: PT Bumi Aksara.

Moh.Rum Arisandy. (2015). Pengaruh Keterampilan dan Pengalaman Kerja Terhadap Pengembangan Karir Pegawai Pada Dinas Pendidikan Kabupaten Donggala, e-Jurnal Katalogis, Vol.3 Nomor 8, ISSN: 23022019, Universitas Tadulako.

Muhamad Gulom. 2019. Pengaruh Kompetensi, Disiplin dan Lingkungan Kerja Terhadap Mutu Pelayanan pada Bank Pembangunan Daerah Kabupaten Tojo Una-Una. Jurnal Ekonomi. Vol.7 No.2, E-ISSN.27226565. Diakses pada tanggal 13 Maret 2021.

Pawit M. Yusup. (2012). Perpektif Manajemen Pengetahuan Informasi, Komunikasi, Pendidikan dan Perpustakaan. Jakarta: Rajawali Pres.

Rony Setiawan dan Nana Dara Priatna. 2005. Pengantar Statistik. Yogyakarta: Graha Ilmu.

Sadono Sukirno, dkk. (2011). Pengantar Bisnis. Jakarta: Kencana.

Sari Rezeki Harahap. (2016). Pengaruh Strategi Pengembangan Sumber Daya Insani Terhadap Peningkatan Kinerja Dan Mutu Pelayanan Pada Pt. Bank Muamalat Indonesia, Tbk Cabang Medan. Sumatera Utara: UIN Sumatera Utara.

Shonia Lingga Pratiwi dan Hendry Cahyono. (2018). Pengaruh Pendidikan Dan Pelatihan Terhadap Peningkatan Kualitas SDM Bank Syariah Pada Bank Syariah Mandiri KCP Lamongan. Jurnal Ekonomi Islam, Volume 1 Nomor 2.

Silpa Hanoatubun. (2020). Dampak Covid-19 Terhadap Perekonomian Indonesia. Volume 2 Nomor 1, ISSN Online: 2716-4446. STKIP Muhammadiyah Enrekang.

Wibowo. 2014. Manajemen Kinerja Edisi keempat. Jakarta: PT RajaGrafindo Persada. 